\title{
Francisco Javier Díez de Revenga, La novela política. Novelistas españolas del siglo XXI y compromiso histórico, Ensayos Literarios, Cátedra Miguel Delibes, Universidad de Valladolid-The City University of New York. Graduate Center, Valladolid, 2012, 239 pp.
}

El nuevo libro del profesor de la Universidad de Murcia e investigador en el campo de la literatura española refleja desde su propio título el corpus elegido y los propósitos de la obra. En el pequeño preámbulo nos explica la génesis de estas páginas, que recogen un Curso de Doctorado impartido en el otoño de 2011 en el Graduate Center de la City University of New York (CUNY) bajo los auspicios de la Cátedra Miguel Delibes, y en las que se detiene de una forma particular en la novela creada por mujeres en España durante la primera década del siglo XXI, basadas todas ellas en el compromiso con la historia más reciente de nuestro país y de Europa. El propio autor apunta el momento exacto en el que surge la idea primigenia: "He de reconocer que la lectura de las novelas de tres amigas, María Dueñas, Clara Sánchez y Almudena Grandes, sin una intención ni profesoral ni investigadora, despertaron en mí un repentino interés por seguir averiguando algo que parecía más común de lo esperable."

Díez de Revenga menciona asimismo el carácter abierto de esta investigación en marcha, que ha requerido de la participación de los estudiantes y de la comunicación estrecha y humanista entre el maestro y los discípulos.

Novelistas como Esther Tusquets, María Jesús Orbegozo, Soledad Puértolas, Carme Riera, Cristina Cerezales Laforet, Alicia Giménez Barlett, Julia Navarro, Dulce Chacón, Clara Sánchez, Ángeles Caso, Almudena Grandes, Belén Gopegui, Rosa Ribas, Ángela Vallvey, Olga Merino, Carmen Amoraga, Marta Rivera de la Cruz y Laia Fabregas constituyen la nómina completa de este estudio original y muy atractivo. Entre las obras destacan las conocidas $E l$ tiempo entre costuras, La voz dormida, Inés y la alegría, Lo que esconde tu nombre, Donde nadie te encuentre, Una palabra tuya y Música blanca.

El catedrático de Literatura española ha ido deteniéndose en distintos aspectos del tiempo histórico al que aluden estos relatos y ha dividido la obra en una media docena de epígrafes, entre los que vale la pena señalar el dedicado a las secuelas de la guerra de España, en el que valora una media docena de títulos referidos a este espacio histórico; asistimos también a una mirada sobre la España durante la segunda guerra mundial, a un análisis acerca del franquismo y sus consecuencias, un capítulo inexcusable dedicado a la España en la Transición, que subtitula con acierto "De la esperanza al desengaño", y un último apartado en el que bucea en la España de la actualidad, sobre todo en la crisis económica y en la crisis social. A modo de conclusión rápida añade Javier Díez de Revenga un epílogo sobre las heroínas modernas, creadas por estas novelistas: "Porque nuestras novelistas, las que han ocupado las reflexiones de este ensayo, han creado heroínas y, al mismo tiempo, han formalizado un concepto muy moderno y actual de la heroína de novela." Hasta este momento la mayor parte de las heroínas novelescas habían sido creadas por hombres, aunque, advierte el profesor casi al final del libro, que Fernán Caballero y Pardo Bazán engendraron sus propios prototipos femeninos narrativos.

Éste es un libro, sin duda, no solo muy interesante, extraordinariamente bien escrito y atento al devenir literario más próximo a nosotros, cuyo contenido el ensayista murciano ha tenido a bien difundir al otro lado del Atlántico, sino que combina el periodo más fecundo, contradictorio, a veces doloroso, pero siempre vivo de nuestro último acontecer político y social, expresado en las novelas de las novelistas escogidas, con la reivindicación de la escritura femenina española y moderna, de calidad y con una visión diferente, que el profesor murciano ha acertado a reflejar en estas páginas con el conocimiento profundo de la literatura que ya le caracteriza y una generosidad digna de resaltar en esa mirada atenta a los últimos libros escritos por mujeres españolas, cuya versión de los hechos cautiva tanto o más que la que desde siempre nos han manifestado los hombres. Mi enhorabuena, por tanto, por este libro cuidado por dentro y por fuera, casi una joya que no deberíamos perdernos los amantes de la novela actual.

Pascual García 